\title{
Study of nitrogen fluxes across conventional solid floor cubicle and compost-bedded pack housing systems in dairy cattle barns located in the Mediterranean area: Effects of seasonal variation
}

\author{
J. Balcells, E. Fuertes, A. R. Seradj, ${ }^{*}$ J. Maynegre, D. Villalba, and G. de la Fuente \\ Department of Animal Science, Agrotecnio Center, Universitat Lleida, Alcalde Rovira Roure 191, Lleida 25198, Catalonia, Spain
}

\section{ABSTRACT}

The aim of this study was to determine the effect of housing system (or manure management system) and season on manure $\mathrm{N}$ recovery and volatilization using an $\mathrm{N}$ mass balance. Dietary, milk, and manure $\mathrm{N}$ were monitored together with outside temperatures in 6 dairy barns. Three barns were designed as conventional freestalls (cubicle, CUB) with an automatic manure scraper system and concrete floor, in which the gutter in the middle was continuously scraped (every 2-4 h) and the slurry was conveyed toward an open-air concrete pool. The other 3 barns were designed as a loose housing system (HS) with a compost-bedded pack (CB) and conventional confinement housing provided with a feed alley that was cleaned mechanically (2-3 times per day). The farms under study were located near Lleida in the center of the Ebro valley, in northeastern Spain. Nitrogen recovery was measured twice under farm-like conditions either during spring-summer (3 mo of increasing temperatures) or fall-winter (3 mo of decreasing temperatures). The number of cows per barn ranged from 99 to 473, and average age, mean lactation, and parturition intervals were $4.1 \mathrm{yr}, 2.43$ lactations, and $426.6 \mathrm{~d}$, respectively. In spring-summer, animals ate more $[26.3$ vs. $23.8 \mathrm{~kg}$ of dry matter $(\mathrm{DM}) / \mathrm{d}]$ and produced more milk (34.6 vs. $31.3 \mathrm{~kg} / \mathrm{d}$ \pm 0.68). However, milk composition did not change. Stored manure from the CB system showed a higher DM concentration with respect to the CUB system (379.15 vs. $97.65 \mathrm{~g} / \mathrm{kg}$ of fresh matter); however, N (31.45 vs. 40.2$), \mathrm{NH}_{3}-\mathrm{N}(5.3$ vs. 18.9) and its ratios with phosphorus $\left(\mathrm{NH}_{3}-\mathrm{N}: \mathrm{P}, 3.52\right.$ vs. 5.2$)$ and potassium $\left(\mathrm{NH}_{3}-\mathrm{N}: \mathrm{K}, 0.615\right.$ vs. 2.69$)$ showed the opposite trend. No differences were found in $\mathrm{N}$ intake $(653$ vs. 629.5 $\mathrm{g} / \mathrm{d}$ ) or milk $\mathrm{N}$ secretion (190 vs. $177.8 \mathrm{~g} / \mathrm{d}$ for CUB and $\mathrm{CB}$ barns, respectively) although net $\mathrm{N}$ recovery of

Received September 7, 2019.

Accepted July 6, 2020.

*Corresponding author: arseradj@ca.udl.cat the excreted $\mathrm{N}\left(\mathrm{N}_{\text {intake }}-\mathrm{N}_{\text {Milk }}\right)$ was significantly lower in manure in CB barns than in CUB systems (193.8 vs. $389.3 \mathrm{~g} / \mathrm{d}$ ). The proportion of $\mathrm{N}$ irreversible loss in relation to the $\mathrm{N}$ intake was higher in $\mathrm{CB}$ than in $\mathrm{CUB}$ barns (42.3 vs. $11.0 \%)$. There was no clear association between season and irreversible $\mathrm{N}$ losses; however, the housing system was pivotal in the association between $\mathrm{N}$ recovery in manure and irreversible losses by volatilization.

Key words: nitrogen losses, manure, housing system, season, dairy cow

\section{INTRODUCTION}

Over the past $20 \mathrm{yr}$, environmental concerns related to livestock production have driven the importance of developing manure management alternatives to mitigate pollution in runoff water, air, and soils. State regulations have been enacted to avoid $\mathrm{N}$ (as nitrates) pollution in vulnerable soils; thus, both manure $\mathrm{N}$ application (per hectare) and production per cow have been targeted (Generalitat de Catalunya, 2009). For this reason, dairy researchers have increasingly encouraged farmers to apply dairy cow rationing to maximize milk $\mathrm{N}$ recovery. However, under commercial conditions, only 20 to $30 \%$ of dietary $\mathrm{N}$ is secreted as milk $\mathrm{N}$ (Powell et al., 2006); the remainder is wasted, mostly through urine as urea N (Bristow et al., 1992). The presence of urease in manure oxidizes urea to ammonia, although its activity is dependent upon $\mathrm{pH}$. When the unstable equilibrium between $\mathrm{NH}_{3}$ and $\mathrm{NH}_{4}{ }^{+}$is altered, ammonium is volatilized and wasted irreversibly as it is released into the atmosphere. Losses of $\mathrm{N}$ as ammonia can reach up to $50 \%$ of manure $\mathrm{N}$ excretions (MWPS, 2001), and the primary factors that alter ammonia $\mathrm{N}$ emissions are diet, housing, and manure handling strategies (Sanchis et al., 2019).

Freestall barns (cubicles, CUB; in which cows are confined in cubicles with a solid floor and manure is regularly collected through a gutter, scraped regularly, and stored for 1 to $5 \mathrm{mo}$ in an open-air concrete pool) are the most common housing system for dairy farms in 
Spain, although compost-bedded pack housing systems (CB) have recently been promoted among farmers.

Compost-bedded barns provide an open resting area surrounded by a retaining wall for manure storage for up to 6 mo (Janni et al., 2007). Milking typically occurs 2 to 3 times per day, which represents a convenient time to work regularly on the compost without cows occupying the resting area (Shane et al., 2010). Common management practices mix manure and urine from the surface into the pack and enhance the aerobic microbial activity and temperature. Under arid conditions, such as those in Israel where the compost-bedded system was originally developed, the bed does not require additional material. However, an optimal dairy cow stocking density requires greater space, with a recommended minimum of $15 \mathrm{~m}^{2}$ per cow when feed alleys are scraped daily and between 20 and $30 \mathrm{~m}^{2}$ when composting is also applied to the feed alley (Klaas et al., 2010).

Compost-bedded pack barns meet the space, exercise, resting, and social needs of cows (Galama, 2011) and may improve animal wellbeing by reducing the incidence of lameness (Lobeck et al., 2011), the mastitis infection rate (Reneau et al., 2005; Barberg et al., 2007), and total SCC counts (Klaas et al., 2010).

Because of the low cost and positive effects on animal welfare, compost-bedded systems have received increasing attention in the semi-arid regions of northeastern Spain. The primary aim of this study was to identify which of the 2 systems - CUB or CB - has the lowest environmental impact in terms of $\mathrm{N}$ recovery. To achieve this aim, we proposed 2 objectives; first, to assess the $\mathrm{N}$ losses from 2 types of commercial dairy farms (CUB and CB); and second, to determine the effect of season, focusing on seasonal variables such as temperature variation (increasing and decreasing) and wind speed. Measurements were restricted to the barn and outdoor storage; aspects related to field manure $\mathrm{N}$ application were outside the scope of this study.

\section{MATERIALS AND METHODS}

Measurements were conducted over two 10-wk seasons; in season I, temperatures were increasing (from February to May), whereas in season II, temperatures were decreasing (from August to November), thus these 2 seasons covered both warm and cold periods of the year. All barns were located in the Lleida area of the Ebro valley, northeaster Spain (for farm localization, see Table 1).

\section{Barn Design and Management}

Measurements were performed in 6 selected commercial dairy cattle barns with different manure handling/

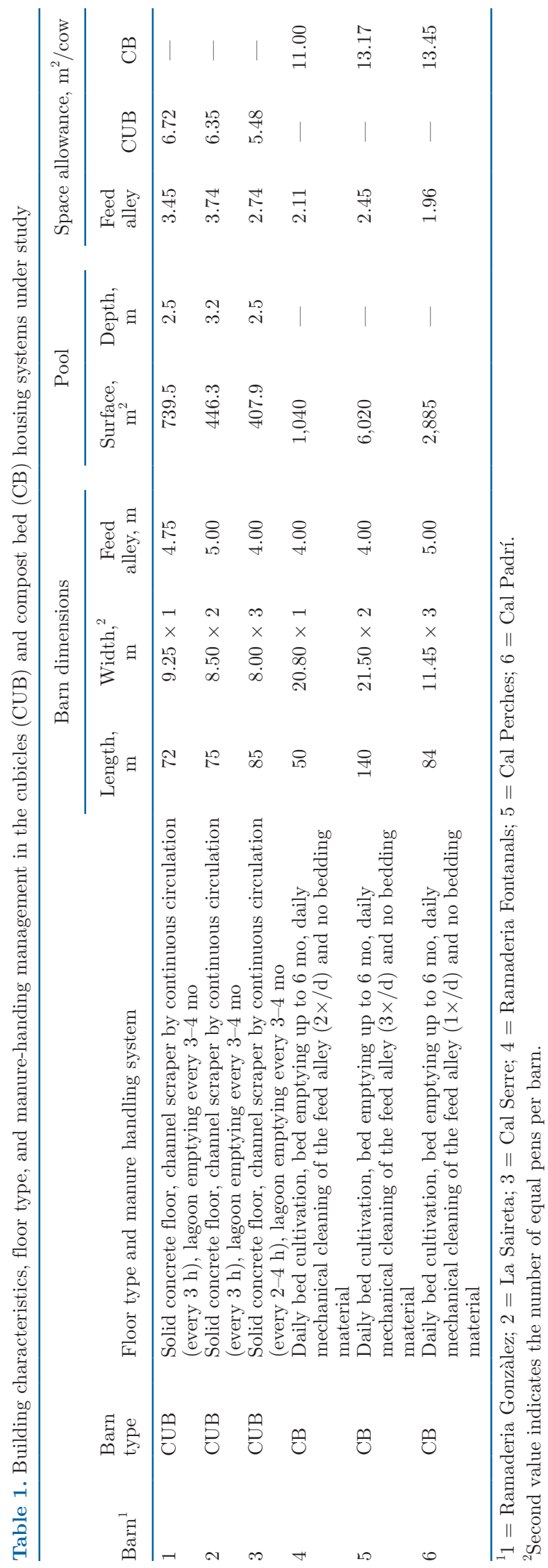


storing systems. Barn selection was performed to seek representativeness among the different managing systems currently used in dairy farms but also to maintain a certain degree of homogeneity between the barns included in the study. Barns 1 and 3 were not compartmented, whereas barns 2 and 4 were divided into 2 equal pens and barns 5 and 6 were divided into 3 equal pens. Milking facilities were placed at the center of the barns, and all were fully open and naturally ventilated and had no differences in natural ventilation practices between the hot and cold seasons. Barn layout and housing equipment differed. Three barns were equipped with a conventional freestall system using cubicles (CUB: 1, 2, and 3) with an automatic manure scraper system and a concrete floor where the deep slurry gutter (30-45 $\mathrm{cm}$ ) in the middle was scraped and slurry was moved outside the barn by circulating scrapers (every 2-4 h) to a concrete open-air pool. The other 3 barns were equipped with a loose housing system with a bedded pack (CB: 4, 5, and 6) and conventional confinement. The compost-bedded pack was tilled daily after the morning milking; moreover, CB barns had a concrete floor feed alley surrounded by a retaining wall designed to isolate the manure deposited into the feed alley or into the compost-bedded pack without disturbing cow mobility. In general, no substrate was used as bedding material, although barley straw was occasionally added to the bedded pack. Extra information about buildings, equipment, and concrete pools is detailed in Tables 1 and 2.

Before this trial, no large-scale studies had been conducted with these herds, which had only been managed for commercial purposes, and it was agreed with the owners that any interference due to sampling and data collection would be minimized to maintain farm-like management practices throughout the trial.

\section{Animal Management}

All farms raised Holstein Friesian cows with from 1 to 4 parturitions. Cows were milked twice or thrice per day (2 barns were milked twice and one thrice in each housing system). On average, animals were artificially inseminated at (approximately) $157 \mathrm{~d}$ after parturition and dry-off, $70 \mathrm{~d}$ before the anticipated next calving, and the mean DIM ratio (lactation period) was $83.6 \%$ (FEFRIC, 2018). Because of the lack of weight-recording systems at the barns and to calculate cattle protein requirements and the balance between undegradable and degradable protein, we assumed a standard constant live weight of $700 \mathrm{~kg}$ (Observatory of Milk and Beef Production, 2018).

\section{Experimental Diet}

Cows received TMR balanced according to Agricultural and Food Research Council (1993) with a minimum of $45 \%$ forage, including corn silage and alfalfa silage to support a daily production of 30 to $35 \mathrm{~kg}$ of milk. Rations for the dairy cows were formulated to maintain an average CP (on DM basis) between $16 \%$ and $17 \%$. Ration compositions are shown in Table 3 ; the amount of TMR offered daily was adjusted to minimize or avoid refusals.

\section{Data and Sample Collection}

In every month of each season, CUB barns (barns 1 to 3 ) were sampled in the first and third weeks, and $\mathrm{CB}$ barns (barns 4 to 6 ) were sampled in the second and fourth weeks of the month. This resulted in 6 sampling days and 5 periods of evaluation per barn.

Feed $N$ Intake. On the sampling day, offered feed (both details and precision of the unified provider are presented in Table 2) and refusals were manually weighed; group DMI was calculated as the DM offered minus the DM refused. Daily samples of the offered TMR (Table 3) were collected, dried for $48 \mathrm{~h}$ at $60^{\circ} \mathrm{C}$ forced-air oven, and stored until further analysis.

Milk N Secretion. Average milk yield was measured daily per barn calculated from the increased volume in the refrigerated tank (for details, see Table 2 ). Every $2 \mathrm{~d}$, refrigerated tanks were sampled to determine milk composition. Milk composition analyses were performed by the Dairy Inter-Professional Association of Catalonia testing service (ALLIC, Cabrils, Spain), and the average milk composition of each barn was calculated using composition values recorded within each 2-wk sampling period.

Manure $N$ Production. For dairy cows under the CUB system, the $\mathrm{N}$ left in the storage pool ( $\left.\mathrm{N} \mathrm{left}_{\text {pool }}\right)$ was assessed on each sampling day. Manure volume was determined by considering the storage pool surface and manure depth; manure depth was considered an averaged value of the depth registered in different spots (up to 10) of the storage pool. Samples from a whole section of semi-solid manure strata were obtained using manure probes consisting of solid PVC tubes (PVC, $10 \mathrm{~cm}$ in diameter and $300 \mathrm{~cm}$ long). The sharp end of the probe was inserted perpendicularly into the surface of the manure pool; when the PVC probe was filled, the other end was hermetically closed, the probe was slowly removed, and the complete sample harvested. Duplicate samples of manure were taken at different spots (up to 10), pooled, and kept frozen at $-40^{\circ} \mathrm{C}$ before further $\mathrm{N}$ concentration analysis. Total $\mathrm{N}$ left ${ }_{\text {pool }}$ 
Balcells et al.: HOUSING SYSTEMS AFFECT N VOLATILIZATION

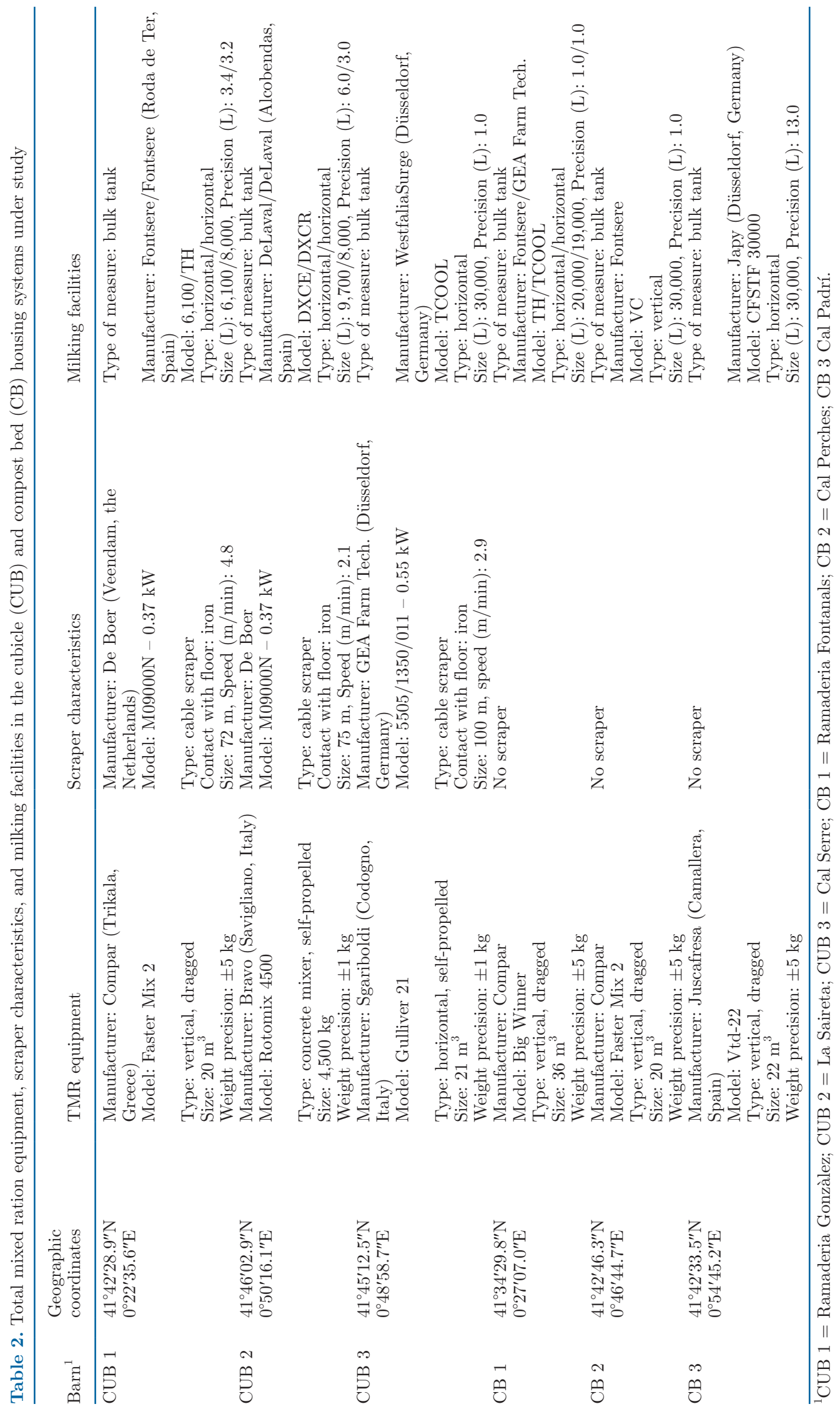


Balcells et al.: HOUSING SYSTEMS AFFECT N VOLATILIZATION

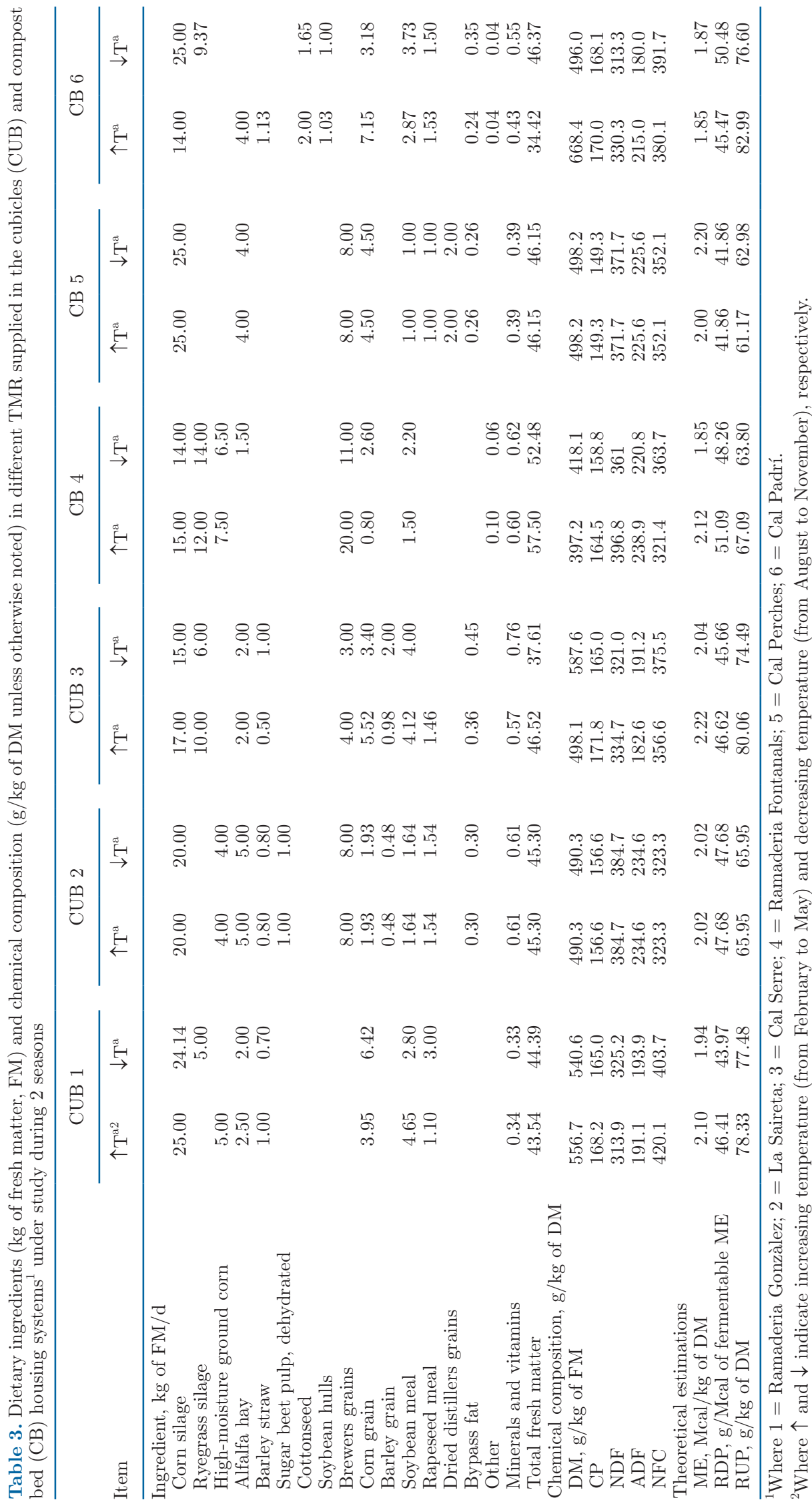


was calculated as the product of the manure volume by the $\mathrm{N}$ concentration of each sampling day.

Manure $\mathrm{N}$ left in the CB barns was also measured for each sampling day but 2 fractions were distinguished, as follows. During the sampling day, manure deposited in the feed alley was scraped and fully collected mechanically ( $2-3$ times per day) using a tractor provided with a shovel, weighed, and sampled [ $\sim 20 \mathrm{~kg}$ of manure fresh matter (FM)], and daily $\mathrm{N}$ left into the feed alley $\left(\mathrm{N}\right.$ left $\left.t_{\text {alley }}\right)$ was calculated as the product of the fresh manure weight by its $\mathrm{N}$ concentration. Once the manure deposited in the feed alley was collected and sampled, it was stored in the dung heap (first fraction). The second fraction corresponded to the manure that was deposited and accumulated in the compost-bedded pack, and it was measured as follows: just after the morning tillage, the volume of the bed was determined by considering bed surface and depth of manure. A steel drill designed for soil sampling $(7 \mathrm{~cm}$ in diameter $\times 100 \mathrm{~cm}$ long, Eijkelkamp, Nijverheidsstraat, Giesbeek, the Netherlands) was used for simultaneous depth measurement and manure sampling from the compost bed. From each compost bed (square), samples (at least 50 spots) were taken diagonally every 4 to $5 \mathrm{~m}$. Spot samples were pooled and analyzed for $\mathrm{N}$ concentrations; $\mathrm{N}$ left in the

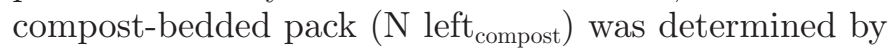
multiplying manure volume by $\mathrm{N}$ concentration.

\section{Sample Analyses}

Samples collected by ALLIC were analyzed using the CombiFoss 5000 (Foss Electric, Hillerød, Denmark) for protein and fat determination by MilkoScan 4000 and MUN by infrared. Feed was ground (1-mm screen diameter) and analyzed for DM and OM. Feed DM was determined with a $105^{\circ} \mathrm{C}$ forced-air oven. Ash was determined using a muffle furnace maintained at $550^{\circ} \mathrm{C}$ for $6 \mathrm{~h}$. Organic matter percentage was calculated as 100 - ash. Feed N was determined by Kjeldahl method (AOAC International, 2010). Neutral detergent fiber was determined on feed samples using $\alpha$-amylase (A3306, Sigma Chemical Co., St Louis, MO) with sodium sulfite and corrected for ash concentration according to Van Soest et al. (1991), and adapted for Ankom $^{200}$ Fiber Analyzer (Ankom Technology, Faiport, NY). After thawing, fresh manure samples were divided in 2 subsamples. The first was used for analysis of total $\mathrm{N}$ and $\mathrm{NH}_{3}-\mathrm{N}$; $\mathrm{N}$ was determined by Kjeldahl method and $\mathrm{NH}_{3}-\mathrm{N}$ concentration was determined by direct distillation with $\mathrm{Na}_{2} \mathrm{~B}_{4} \mathrm{O}_{7}$. The second was dried in a $105^{\circ} \mathrm{C}$ forced-air oven, ground and analyzed for DM, OM, and $\mathrm{CP}$ as described above. Phosphorus and potassium contents were analyzed by atomic emission spectro- photometry (Thermo ICAP 6300 DUO Waltham, MA) following Porta et al. (1982).

\section{Environmental Parameters}

During the experimental period, temperature and wind speed of the area were obtained from the closest climatic control stations; averaged values are presented on a weekly basis (Figure 1). For the location of the meteorological stations used as a reference [Vallfogona de Balaguer $\left(41^{\circ} 47^{\prime} 08.1^{\prime \prime} \mathrm{N} \quad 0^{\circ} 49^{\prime} 40.5^{\prime \prime} \mathrm{E}\right)$, El Poal $\left(41^{\circ} 40^{\prime} 15.0^{\prime \prime} \mathrm{N} 0^{\circ} 52^{\prime} 37.7^{\prime \prime} \mathrm{E}\right)$, and Gimenells $\left.\left(41^{\circ} 39^{\prime} 22.4^{\prime \prime} \mathrm{N} 0^{\circ} 23^{\prime} 22.8^{\prime \prime} \mathrm{E}\right)\right]$, geographical homogeneity of the area and closeness of the barns (the distance from the barns to the closer station was less than 25 $\mathrm{km}$ ) allowed for a representative description of the climatological situation of the barn climate.

\section{Calculations and Statistical Analyses}

Manure Density Determination. Each sampling day, manure volume was converted to mass by determining the density. Density was determined using 2 protocols: (1) density of slurry samples (liquid or semiliquid samples) coming from concrete pools and feed alleys was obtained by the coefficient $\mathrm{d}[\mathrm{d}=\mathrm{M} / \mathrm{V}]$ between mass (M) and volume (V) of the samples; (2) density in solid manure from CB barns (solid material) was obtained as follows: 3 whole-depth grooves (pits) were mechanically excavated in the bed (about $5 \mathrm{~m}$ long and $0.4 \mathrm{~m}$ wide) using a tractor, and for each groove, the cross section was proportionally divided into 3 levels [bottom, near to the bed floor, middle, and surface level). For each level, 3 volumetric metallic rings $(55 \mathrm{~mm}$ internal diameter and $7 \mathrm{~cm}$ thickness, Eijkelkamp) were introduced into the manure, and the complete volume was extracted and weighed. Thus, manure density was calculated as the mean value of all volume and weight samples from the rings.

Experimental $N$ Losses from Manure Storage. Nitrogen left in concrete pools (CUB system) and the bedded pack ( $\mathrm{CB}$ system) manure correspond to $\mathrm{N}$ production minus $\mathrm{N}$ lost during storage; however, measures of $\mathrm{N}$ left in the fresh daily manure from the feed alley ( $\mathrm{CB}$ barns) refer only to the $\mathrm{N}$ production. To estimate $\mathrm{N}$ losses from manure collected and stored in the dung heap (coming from the feed alley in CB barns), a manure pool simulator (MPS) was designed to replicate the manure condition registered in the dung heap. The manure pool simulator consisted of a plastic barrel (85 cm diameter and $160 \mathrm{~cm}$ height) placed near the dung heap and maintained under the same environmental conditions. One MPS was placed in each of the 


\section{$-\Delta$ - Temperature —Wind Speed}
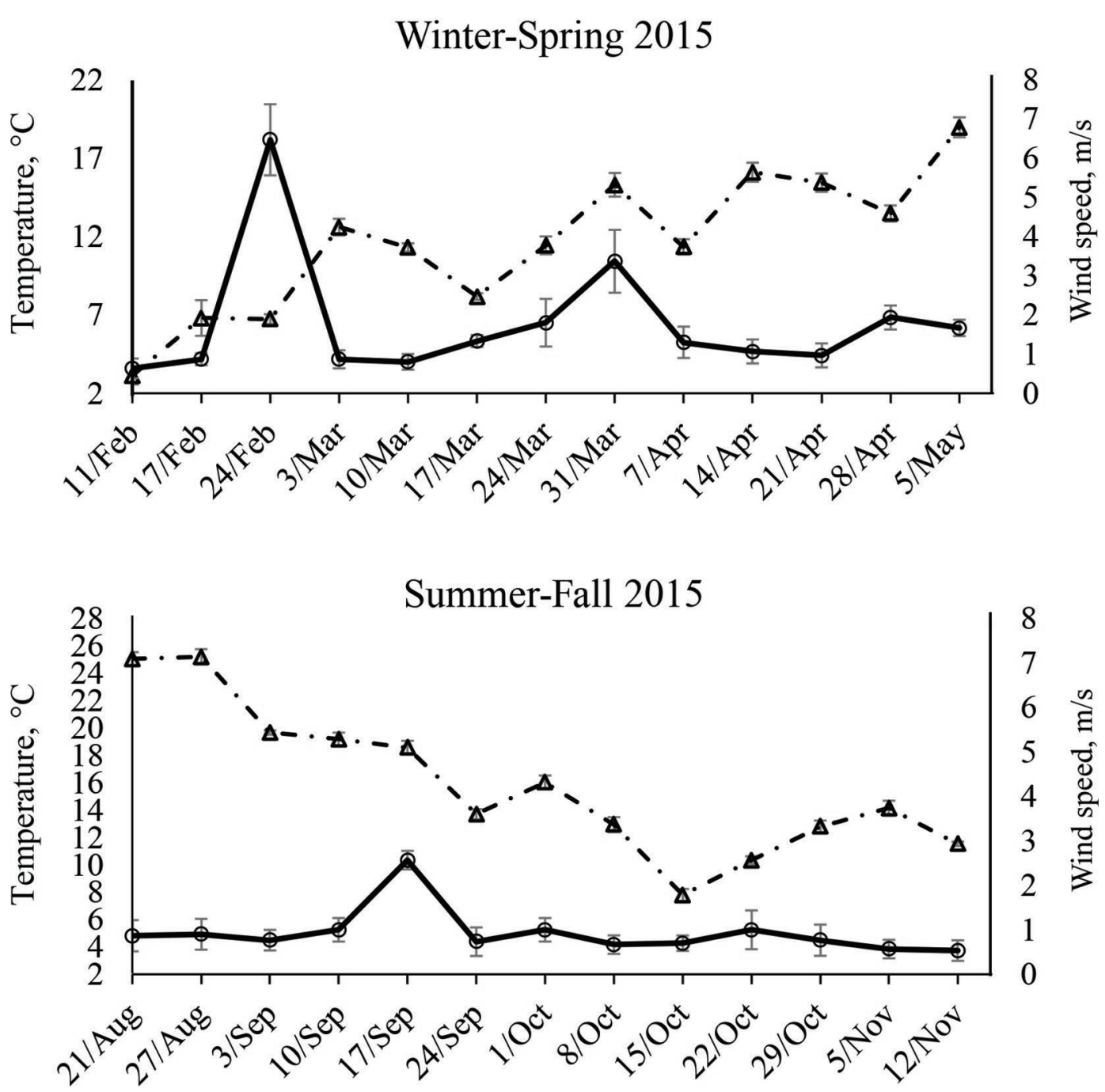

Figure 1. Changes in weekly temperature $\left({ }^{\circ} \mathrm{C}\right.$ ) and wind speed (at $2 \mathrm{~m}$ height; $\mathrm{m} / \mathrm{s}$ ) during the 2 seasons of the study. Error bars indicate $\mathrm{SD}$.

analyzed barns, and the fresh manure added to the simulator was calculated to be equivalent to the increase in the manure depth registered in the dung heap. On each sampling day, a representative quantity of fresh manure was added to the MPS, with the sampling procedure as follows: several (25-50 spot samples, $0.5-1$ $\mathrm{kg}$ of FM) samples of fresh manure were taken from the alleys, pooled, subsampled, weighed, and directly added $(20-40 \mathrm{~kg})$ to the MPS. Every sampling day $(i=1$ to 6) $\mathrm{N}$ stored in the MPS ( $\left.\mathrm{N} \operatorname{stored}_{\mathrm{MPS} i}\right)$ was calculated as the sample weight multiplied by the $\mathrm{N}$ concentration. At the end of each season, total MPS manure was weighed, sampled, and analyzed to calculate $\mathrm{N}$ left in the MPS ( $\mathrm{N}$ left ${ }_{\mathrm{MPS}}$ ). Differences between $\mathrm{N}$ stored in the MPS, calculated as the summation
$\sum_{i=1}^{6}\left(\mathrm{~N} \operatorname{stored}_{\mathrm{MPS} i}\right)$ and $\mathrm{N}$ left $\mathrm{MPS}_{\mathrm{MP}}$ were considered a valid index of the $\mathrm{N}$ losses from the manure stored in the dung heap. An MPS-lost coefficient $(k)$ in grams of $\mathrm{N}$ lost/grams of $\mathrm{N}$ stored was calculated as follows:

$$
k=\frac{\left[\sum _ { i = 1 } ^ { 6 } \left(\mathrm{N}_{\text {stored } \left.\left._{\mathrm{MPS} i}\right)\right]-\left(\mathrm{N} \mathrm{left}_{\mathrm{MPS}}\right)}\right.\right.}{\sum_{i=1}^{6}\left(\mathrm{~N} \operatorname{stored}_{\mathrm{MPS} i}\right)} .
$$

$N$ Mass Balance Calculations. Mass N balance and $\mathrm{N}$ losses $\left(\mathrm{N}_{\text {in }}-\mathrm{N}_{\text {out }}\right)$ were calculated for each period of sampling with the following equation: $\mathrm{N}$ balance $(\mathrm{g} / \mathrm{d}$ per cow $)=$ intake $\mathrm{N}-$ milk $\mathrm{N}$ - manure $\mathrm{N}$, where 
Table 4. Cows' performance and milk composition parameters in the cubicles (CUB) and compost bed (CB) housing systems under study during 2 seasons

\begin{tabular}{|c|c|c|c|c|c|c|c|c|c|}
\hline Variable & \multicolumn{2}{|c|}{ Housing system } & SEM & \multicolumn{2}{|c|}{ Season $^{1}$} & SEM & \multicolumn{3}{|c|}{$P$-value ${ }^{2}$} \\
\hline Wind speed, $\mathrm{m} / \mathrm{s}$ & 1.31 & 1.44 & 0.060 & 1.82 & 0.92 & 0.0554 & 0.12 & 0.001 & 0.18 \\
\hline Temperature, ${ }^{\circ} \mathrm{C}$ & 14.5 & 14.3 & 0.17 & 16.5 & 12.3 & 0.18 & 0.53 & 0.001 & 0.27 \\
\hline \multicolumn{10}{|l|}{ Herd structure } \\
\hline Cows, no. & 224 & 255 & 94.0 & 248 & 231 & 67.0 & 0.74 & 0.85 & 0.99 \\
\hline Parturition interval, d & 426.6 & 438.5 & 6.92 & 433.5 & 431.6 & 4.92 & 0.10 & 0.79 & 0.98 \\
\hline \multicolumn{10}{|l|}{ Herd performance } \\
\hline DMI, kg/d & 25.2 & 24.7 & 0.62 & 26.2 & 23.7 & 0.59 & 0.94 & 0.03 & 0.07 \\
\hline Milk yield, kg/d & 33.9 & 32.1 & 1.34 & 34.6 & 31.4 & 1.39 & 0.22 & 0.05 & 0.46 \\
\hline \multicolumn{10}{|l|}{ Milk composition, $\mathrm{g} / \mathrm{kg}$} \\
\hline Fat & 34.7 & 35.3 & 0.92 & 34.8 & 35.2 & 0.86 & 0.71 & 0.81 & 0.13 \\
\hline Protein & 33.1 & 33.9 & 0.40 & 33.5 & 33.5 & 0.30 & 0.02 & 0.85 & 0.97 \\
\hline
\end{tabular}

${ }^{1}$ Where $\uparrow$ and $\downarrow$ indicate increasing temperature (from February to May) and decreasing temperature (from August to November), respectively. ${ }^{2} \mathrm{HS}=$ housing system; $\mathrm{S}=$ season; $\mathrm{HS} \times \mathrm{S}=$ interaction of housing system and season.

intake $\mathrm{N}(\mathrm{g} / \mathrm{d}$ per cow $)=\mathrm{DMI}(\mathrm{kg} / \mathrm{d}$ per cow $) \times$ ration $\mathrm{N}(\mathrm{g} / \mathrm{kg}$ of $\mathrm{DM})$ and milk $\mathrm{N}(\mathrm{g} / \mathrm{d}$ per cow $)=$ milk production $(\mathrm{kg} / \mathrm{d}$ per cow $) \times$ milk $\mathrm{N}(\mathrm{g} / \mathrm{kg}$ of milk) .

The increase in manure $\mathrm{N}$ (fecal plus urinary $\mathrm{N}, \mathrm{g} / \mathrm{d}$ per cow) for each period was calculated using $\mathrm{N}$ left from the 2 samplings $(i$ and $i+1)$ from the period $(\mathrm{Pd})$ and accounting for the number of cows as follows:

$$
\begin{aligned}
& \text { Manure } \mathrm{N}=
\end{aligned}
$$

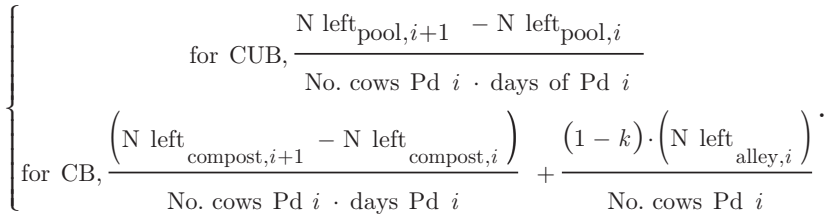

\section{Statistical Analyses}

Barn was considered the experimental unit for statistical purposes but results were expressed on per day and per cow bases. Data were analyzed with the MIXED procedure in SAS (version 9.4; SAS Institute Inc., Cary, NC). Dry matter intake, milk, and milk-N yield, MUN, feed efficiency (milk yield/DMI), and N mass balance variables were analyzed using the model represented in following equation:

$$
Y_{i j k l}=\mu+H S_{i}+W_{j}+S_{k}+(H S \times S)_{i j k}+\varepsilon_{i j k l}
$$

where $Y_{i j k l}$ is a measurement from a herd of cows allocated in each barn, $\mu$ is the overall mean; $H S_{i}$ is the manure management system (CUB, CB); $W_{j}$ is the weekly effect and is treated as a repeated measure $(j$ $=1$ to 5 ); $S_{k}$ is the seasonal effect (season I, increasing temperature; season II, decreasing temperature); $H S \times S$ is the interaction effect among the previously described effects, and $\varepsilon_{i j k l}$ is the residual error. Statistical significance was declared at $P<0.05$ and trends at $0.05<P<0.10$. Variances of wind speed between 2 experimental seasons were analyzed using Fisher exact test, which was performed at level of 0.05 .

\section{RESULTS}

In most of the analyzed parameters the interactions were negligible and results are presented as main effects (Tables 4 and 6); however, in manure composition data (Table 5), when there were significant interactions, interaction means are presented.

\section{Barn Management}

No specific changes in dairy management during the experimental period were recorded, although in barn 3 (CUB barns), the slurry pool was partially emptied in the middle of experimental season I; however, volumes had been recorded and samples taken. In barn 4 (CB barns) during the fall-winter season, some substrate material (barley straw) was used and the edges of the composting bed were mechanically emptied to prevent excess humidity; in both cases, manure and bedding $\mathrm{N}$ were measured and controlled. 


\section{Diet Composition}

Diets were formulated based on the recommendation of the Agricultural and Food Research Council (1993), and the ingredients and chemical and nutritional compositions of the rations are tabulated in Table 3. At the barn, and before serving each meal (twice a day), ingredients in the ration were mixed using a TMR mixer and sampled as previously described. Diets were based on corn (silage and grain) and soybean meal as primary ingredients. No specific changes related to season were applied to the rationing.

Throughout the experimental period, CP values were between 14.0 and $17.0 \%$ DM, predicted RDP values were 4.65 and 4.63 , and RUP values were 7.26 and 7.02 for seasons I and II, respectively. No apparent differences in NDF, ADF, and NFC were recorded, although $\mathrm{NDF}(\mathrm{g} / \mathrm{kg}$ of DM) was numerically higher in season I than in season II diets (355.3 vs. 346.15 for NDF and 214.6 vs. 207.7 for ADF), whereas the opposite was observed for NFC (358 vs. $368 \mathrm{~g} / \mathrm{kg}$ of DM). Overall, data summarized in Table 3 show no significant differences in nutrient intake between seasons and housing systems.

\section{Herd Conditions, Structure, and Performance}

Environmental Variables. No differences between management systems were registered in the average temperatures (14.5 vs. $14.3^{\circ} \mathrm{C}$ for $\mathrm{CUB}$ and $\mathrm{CB}$, respectively); however, average outside temperatures registered during season I (February-May; $16.5^{\circ} \mathrm{C}$ ) were higher $(P<0.001)$ than average temperature during season II (August-November, $12.3^{\circ} \mathrm{C}$ ). Average wind speed recorded did not differ between management systems (1.31 vs. $1.44 \mathrm{~m} / \mathrm{s}$ for $\mathrm{CUB}$ and $\mathrm{CB}$, respectively) but winter-spring season was windier (1.82 vs. $0.92 \mathrm{~m} / \mathrm{s}$; for seasons I and II respectively SEM: 0.554; $P<0.001)$ and showed a higher variance $(1.32$ and 0.23 for seasons I and II, respectively; $P<0.05)$ as index of changes on wind speeds or directions. Changes in weekly temperatures and wind episodes during both seasons are shown in Figure 1.

Herd Structure and Performance. Although farms were chosen using a homogeneity criterion based on barn characteristics (i.e., facilities, design, and excreta collection system), the number of cows was not homogeneous among barns and ranged from 99 to 473 animals. Herd size was kept constant within but not

Table 5. Manure composition in dairy cows in the cubicles (CUB) and compost bed (CB) housing systems under study during 2 seasons

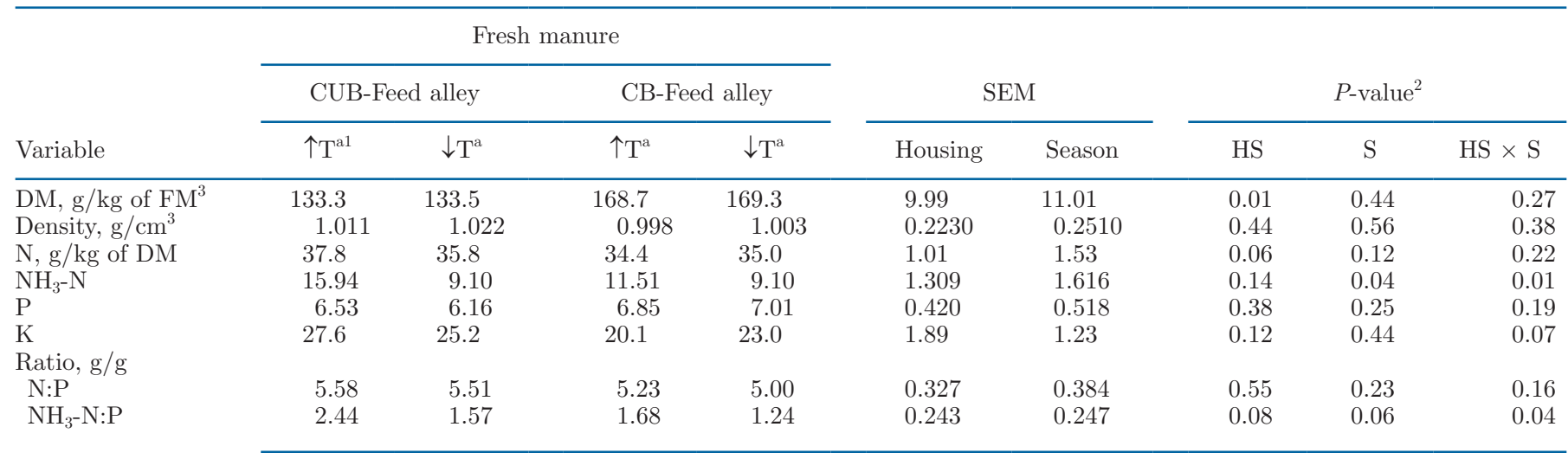

\begin{tabular}{|c|c|c|c|c|c|c|c|c|c|}
\hline & \multicolumn{4}{|c|}{ Stored manure } & & & & & \\
\hline & $\uparrow \mathrm{T}^{\mathrm{a}}$ & $\downarrow \mathrm{T}^{\mathrm{a}}$ & $\uparrow \mathrm{T}^{\mathrm{a} 3}$ & $\downarrow \mathrm{T}^{\mathrm{a} 4}$ & Housing & Season & HS & S & $\mathrm{HS} \times \mathrm{S}$ \\
\hline DM, g/kg of FM & 101.6 & 93.7 & 342.0 & 416.3 & 32.83 & 32.42 & 0.001 & 0.19 & 0.04 \\
\hline Density, $\mathrm{g} / \mathrm{cm}^{3}$ & 1.021 & 1.024 & 0.866 & 0.968 & 0.0700 & 0.1010 & 0.10 & 0.33 & 0.28 \\
\hline $\mathrm{N}, \mathrm{g} / \mathrm{kg}$ of $\mathrm{DM}$ & 39.4 & 41.0 & 31.5 & 30.4 & 2.31 & 3.08 & 0.001 & 0.47 & 0.23 \\
\hline \multicolumn{10}{|l|}{ Ratio, g/g } \\
\hline $\mathrm{N}: \mathrm{P}$ & 5.41 & 5.02 & 3.64 & 3.40 & 0.441 & 0.422 & 0.001 & 0.31 & 0.28 \\
\hline $\mathrm{NH}_{3}-\mathrm{N}: \mathrm{P}$ & 2.72 & 2.67 & 0.57 & 0.66 & 0.683 & 0.721 & 0.001 & 0.26 & 0.54 \\
\hline
\end{tabular}

${ }^{1}$ Where $\uparrow$ and $\downarrow$ indicate increasing temperature (from February to May) and decreasing temperature (from August to November), respectively. ${ }^{2} \mathrm{HS}=$ housing system; $\mathrm{S}=$ season; HS $\times \mathrm{S}=$ interaction of housing system and season.

${ }^{3} \mathrm{FM}=$ fresh matter. 
between seasons, and one of the CB barns suffered a significant reduction in the herd size, from 109 in season I to 80 in season II. Therefore, although mean herd size was higher for $\mathrm{CB}$ barns during season I, differences were not significant (Table 4; $P<0.74$ ) due to the high coefficient of variation registered $(>20 \%)$.

Average cow age, lactation number, and parturition interval were similar between seasons, although the number of lactations was higher in CUB (2.43) compared with CB barns (2.23; $P<0.001)$. Moreover, parturition interval in CUB ( $427 \mathrm{~d})$ tended to be shorter than in $\mathrm{CB}$ structures $(439 \mathrm{~d} ; P<0.10)$. In relation to herd performance, milk composition was not significantly affected by HS; however, mean milk protein was slightly higher in CB than in CUB barns (33.9 vs. 33.1 $\mathrm{g}$ of protein $/ \mathrm{kg}$ of fresh milk; $P<0.02$ ).

Season had a significant effect on herd performance (Table 4). Higher intake (26.3 vs. $23.8 \mathrm{~kg}$ of DMI/d; $P$ $<0.03)$ and milk production (34.6 vs. $31.3 \mathrm{~kg} / \mathrm{d}$ milk yield; $P<0.05$ ) were observed during season I (February-May) because of the longer lighting period and lower temperatures, although neither milk composition nor feed efficiency $(P>0.05)$ was altered by season.

\section{Manure Composition}

Housing System Effect. In fresh samples, slurry DM $(\mathrm{g} / \mathrm{kg})$ was higher in CB than in CUB barns (133.4 vs. 169.0; $P<0.01$ ), although no differences were detected in slurry density, which averaged $1.01 \mathrm{~g} /$ $\mathrm{cm}^{3}$ (SEM: 0.091). The concentration of $\mathrm{N}(\mathrm{g} / \mathrm{kg} \mathrm{DM})$ in fresh (unstored) manure samples harvested in CUB barns was slightly higher than that in CB barns (36.8 vs. 34.7, respectively; $P<0.06)$. In stored manure, there was a significant interaction between housing system and season for DM concentration $(P<0.05)$ : manure DM was higher in CB than in CUB systems
(379 vs. $98 \mathrm{~g} / \mathrm{kg}$ of FM; $P<0.001$ ), but season only altered DM composition in CB barns, being higher in spring-summer than in fall-winter (342.0 vs. $416.3 \mathrm{~g} /$ $\mathrm{kg}$ of $\mathrm{FM}$ ). In stored manure samples, density values in CUB $\left(1.022 \mathrm{~g} / \mathrm{cm}^{3}\right)$ were similar to values registered in fresh samples, but those harvested from the bedded pack (CB barns) tended to show a lower density (1.022 vs. $0.917 \mathrm{~g} / \mathrm{cm}^{3}$ for CUB and CB barns respectively; $P<0.1$ ). In stored manure, both N (31 vs. $40 \mathrm{~g} / \mathrm{kg}$ of $\mathrm{DM})$ and $\mathrm{NH}_{3}-\mathrm{N}$ (5.4 vs. $18.9 \mathrm{~g} / \mathrm{kg}$ of $\left.\mathrm{DM}\right)$ concentrations were significantly lower in CB barns than in CUB barns (N; $P<0.001$ and $\mathrm{NH}_{3}-\mathrm{N} ; P<0.01$ ). In addition, the ratio of $\mathrm{N}$ and $\mathrm{NH}_{3}-\mathrm{N}$ to $\mathrm{P}$ was significantly lower in $\mathrm{CB}$ barns than in CUB barns $(\mathrm{N}: \mathrm{P}, 3.5$ vs. $5.2, P<$ $0.001 ; \mathrm{NH}_{3}-\mathrm{N}: \mathrm{P} 0.61$ vs. $\left.2.69, P<0.001\right)$.

Seasonal Effect. Chemical composition of fresh manure samples was affected by season (Table 5). Fresh manure samples collected during season I (increasing temperatures) were higher in $\mathrm{NH}_{3}-\mathrm{N}(13.7$ vs. $9.1 \mathrm{~g} / \mathrm{kg}$ of DM; $P<0.05)$ when expressed as absolute values with respect to season II (decreasing temperatures). An interaction between housing and season was observed, with $\mathrm{NH}_{3}-\mathrm{N}$ :K being higher in manure from CUB system only during the spring-summer season (interaction $\mathrm{HS} \times \mathrm{S} ; P<0.04)$.

Season had a minor effect on the chemical composition of the stored manure samples. An interaction between housing system and season was observed in DM content of stored manure that was more pronounced in CB structures. During season I, the K concentration was significantly lower in $\mathrm{CB}$ manure than in that from CUB $(P<0.05)$.

\section{N Balance}

Nitrogen balance $(\mathrm{g} / \mathrm{d})$ and losses in dairy and dry cows on a per season and a per housing system basis

Table 6. Nitrogen balance (g/d) and N emission of milking cows in the cubicles (CUB) and compost bed (CB) housing systems under study during 2 seasons

\begin{tabular}{|c|c|c|c|c|c|c|c|c|c|}
\hline Variable & \multicolumn{2}{|c|}{ Housing system } & $\mathrm{SEM}^{4}$ & \multicolumn{2}{|c|}{ Season $^{1}$} & SEM & \multicolumn{3}{|c|}{$P$-value ${ }^{2}$} \\
\hline $\mathrm{N}$ intake & 653 & 629.5 & 10.35 & 671.3 & 611.2 & 11.40 & 0.17 & 0.005 & 0.03 \\
\hline $\mathrm{N}$ excretion & 463 & 451.6 & 8.53 & 473.6 & 441.5 & 10.51 & 0.46 & 0.069 & 0.11 \\
\hline $\mathrm{N}$ deposited into the alley & - & 114.8 & 14.61 & 135.35 & 94.35 & 17.70 & - & 0.17 & - \\
\hline Theoretical $\mathrm{N}$ losses & 13.6 & 15 & 1.32 & 15.6 & 14.3 & 3.62 & 0.63 & 0.4 & 0.71 \\
\hline Total $\mathrm{N}$ left in manure & 389.3 & 193.8 & 27.21 & 304.5 & 280.6 & 21.46 & 0.0002 & 0.45 & 0.77 \\
\hline $\mathrm{N}$ losses & 73.6 & 255.8 & 31.92 & 193 & 136.5 & 26.14 & 0.0012 & 0.16 & 0.65 \\
\hline $\mathrm{N}$ losses, $\%$ of $\mathrm{N}$ intake & 11.1 & 42.3 & 4.85 & 28.9 & 21.9 & 4.02 & 0.009 & 0.1 & 0.96 \\
\hline
\end{tabular}

${ }^{1}$ Where $\uparrow$ and $\downarrow$ indicate increasing temperature (from February to May) and decreasing temperature (from August to November), respectively. ${ }^{2} \mathrm{HS}=$ housing system; $\mathrm{S}=$ season; $\mathrm{HS} \times \mathrm{S}=$ interaction of housing system and season. 
are shown in Table 6. Nitrogen flows were affected, to a different degree, by both housing system and season.

Housing System. Nitrogen intake, milk N, and theoretical $\mathrm{N}$ excretion $\left(\mathrm{N}_{\text {intake }}-\mathrm{N}_{\text {milk }}\right)$ were not influenced by housing system; however, $\mathrm{N}$ left in manure was highly modified by the housing system. In conventional CUB barns, an average of $653 \mathrm{~g}$ of N/d per cow was ingested, whereas $\mathrm{N}$ excretion in the forms of milk and slurry were 190 and $389(\mathrm{~g}$ of N/d per cow), respectively. Therefore, $73.6 \mathrm{~g}$ of $\mathrm{N} / \mathrm{d}$ per cow was irreversibly lost, probably through volatilization representing $11.1 \%$ of the total $\mathrm{N}$ intake. In CB barns, cows deposited $114.8 \mathrm{~g}$ of $\mathrm{N} / \mathrm{d}$ (approximately $30 \%$ of the theoretical $\mathrm{N}$ excretion) in the front alley, and the rest (336.8 g of $\mathrm{N} / \mathrm{d}$ per cow, approximately $70 \%$ of the theoretical $\mathrm{N}$ excretion) into the compost bed. Recovered $\mathrm{N}$ in the dung heap and compost bed was measured as 98.2 and $98.0 \mathrm{~g}$ of $\mathrm{N} / \mathrm{d}$ per cow, respectively (Table 6). Therefore, calculated $\mathrm{N}$ irreversibly lost $(255.8 \mathrm{~g} / \mathrm{d} ; 84.1 \%)$ differed significantly between housing systems $(P<0.01)$.

Season. In season I (when temperature increased), $\mathrm{N}$ intake $(P<0.05)$, milk yield $\mathrm{N}(P=0.03)$, and calculated $\mathrm{N}$ excretion $(P=0.07)$ were higher than in season II.

\section{DISCUSSION}

\section{Experimental Design}

In this experiment, we aimed to calculate $\mathrm{N}$ losses in 2 dairy housing systems using the input-output $\mathrm{N}$ balance procedure. Accurate estimates of $\mathrm{NH}_{3}$ emissions calculated from mass balance requires that $\mathrm{N}$ contained in the rations, milk, and manure is precisely detailed; then, unaccounted $\mathrm{N}$ is assumed to be lost as gaseous $\mathrm{N}$. Because emissions are estimated as the residual of this accounting, any errors in measuring or estimating the mass of $\mathrm{N}$ in each of the individual procedures will be transferred to the final emission estimate. It is true that alternatives to $\mathrm{N}$ mass balance do exist (i.e., methods to monitor gas emissions) although they are also subject to specific restrictions (Harper, 2005) and show a high experimental variation (Leytem et al., 2011). Considering the methodological restrictions and the main objective of this study (to compare mass $\mathrm{N}$ production in 2 types of manure management systems and their seasonal variations), $\mathrm{N}$ flows were accurately measured and losses minimized throughout all the operations; moreover, measurements were conducted in both housing systems simultaneously for each season. As a matter of self-validation, study values regarding $\mathrm{N}$ intake, $\mathrm{N}$ excretion, and $\mathrm{N}$ left in the manure agree with authors working in similar conditions (Hristov et al., 2011). Nevertheless, existing results on $\mathrm{NH}_{3}$ emissions are quite variable with a significant unexplained residual component; in this sense, it is necessary to consider uncontrolled factors that might alter $\mathrm{NH}_{3}$ concentration within the manure and the proportion of $\mathrm{NH}_{3}$ emitted to the atmosphere, some of them related to animal (Bjerg and Klaas, 2014) or environmental conditions (Sanchis et al., 2019).

With these considerations in mind, $\mathrm{N}$ left in manure storage was based on weight (feed alley's manure) or volume, when weight records could not be taken (calculated from the dimension of storage); this was the case for manure deposited into the compost-bedded pack or slurry pool, and when transforming volume to mass manure density factors were applied.

Nitrogen concentrations in manure are heterogeneous, with significant variations in $\mathrm{N}$ content; therefore, a protocol including collection of a large number of samples (especially in compost-bedded pack barns) was designed and applied to obtain a consistent and representative database referring to both manure density and $\mathrm{N}$ concentration. An estimation of mass $\mathrm{N}$ content in the various manure storage compartments allowed for corrections to be made as a result of changes in volume due to increases in the moisture content (i.e., through rain, spilling, and cleaning water) and evaporation. Moreover, any addition of substrate (barley straw) or slurry removed from the pools was quantified and accounted for in subsequent calculations.

Finally, both temperature and wind conditions were gathered from the 3 nearest climatologic stations. The central-northern sector of the Ebro Basin is a relatively flat area, with an average altitude of $250 \mathrm{~m}$ above sea level and an even topography disturbed only by flat mesas, topped by ancient pediment deposits. The short distance between the study sites $(25 \mathrm{~km}$ along an eastwest straight line) contributed to homogeneous climatic conditions for all 6 barns used.

\section{Barns, Management, and TMR Characteristics}

Barn selection was performed according to design homogeneity criteria. However, a certain variability (in terms of available area per cow) remained within barns of the same housing system, particularly in CB barns (from 11.0 to $13.6 \mathrm{~m}^{2} / \mathrm{cow}$ ). For the alleys, variability in area per cow $\left(\mathrm{m}^{2} / \mathrm{cow}\right)$ was higher in CUB barns (3.31) than in CB (2.17). However, based on field observations, the available area in the alleys did not seem to compromise cow eating behavior.

Preliminary results indicated that in freestall $\mathrm{cu}-$ bicles (barns 1 to 3), continuous circulation of the scraper allowed, over the long term, complete emptying of the daily slurry produced in the alley, and thus, no 
significant manure accumulation was observed. During the scraping interval ( 2 to $4 \mathrm{~h}$ ), manure did remain in the alley and some $\mathrm{N}$ losses could have occurred (Monteny et al., 1998); moreover, poor cleaning effectiveness of the scraper could increase $\mathrm{N}$ leakage (Snoek et al., 2017) although these potential losses should be considered inherent to the housing system.

Cows were given time to stand up and defecate before walking away from the alleys toward the milking parlors; however, excreta from the milking intervals (approximately $1 \mathrm{~h}$ at each milking) that was placed outside of the alleys or beds were not considered. Considering existing data on manure production in this time period reported by White et al. (2001), this error would have been small. However, even if manure losses did exist, bearing in mind that milking parlors were placed (in both housing systems) at one end of the barns, uncontrolled losses of $\mathrm{N}$ should be minor and of similar relevance when both collection/storage systems are compared (CUB vs. CB).

During both seasons, dietary $\mathrm{CP}$ levels ranged from 14.9 to $17.2 \%$ of DM; ME reached 2.05 and $1.98 \mathrm{Mcal} /$ $\mathrm{kg}$ of $\mathrm{DM}$, and fermentable ME (Mcal $/ \mathrm{kg}$ ) values were 1.64 and 1.64 for seasons I and II, respectively. Predicted RDP supply $(46.4 \pm 4.62 \mathrm{~g} /$ Mcal of fermentable $\mathrm{ME}$ ) was similar to the value proposed by the Agricultural and Food Research Council (1993), so neither a potential restriction on microbial growth nor an excess of urinary $\mathrm{N}$ excretion was expected. However, RUP supply exceeded $20 \%$ of estimated requirements (Agricultural and Food Research Council, 1993) when using current TMR ingredients and cow performances. This excess has commonly been used as a safety margin to prevent potential nutrient deficiencies related to the animal's requirements. Such nitrogen, which does not contribute to the cow's metabolic requirements, will be lost through the excreta. Animal parameters under consideration were cow age, lactation number, and parturition interval. Moreover, milk yield and chemical composition (see Table 4) did not differ with respect to the average values registered and proposed in this area (FEFRIC, 2018) with a dairy system based on indoor production and the extensive use of corn silage as a primary roughage source.

\section{Spot Sampling}

Differences in the chemical composition of fresh samples of manure harvested from the alleys on sampling days were minimal, although slurry from CB alleys had higher DM and lower $\mathrm{NH}_{3}-\mathrm{N}$ concentrations. The fact that slurry from CUB was continuously cleaned, whereas cleaning in $\mathrm{CB}$ alleys was performed twice a day might have contributed to these differences. Moreover, because of the low wall that separated the feeding alleys from the compost beds, manure in CB alleys might have been contaminated with bed manure because the alleys were continuously crossed by cows moving from the feeders to the resting area. Thus, continuous contamination of fresh slurry with bed pack manure could have contributed to some of the observed differences in $\mathrm{DM}$ and $\mathrm{N}$ concentrations.

Season affected both absolute and relative $\left(\mathrm{NH}_{3}-\mathrm{N}: \mathrm{P}\right.$ ratio) concentrations of $\mathrm{NH}_{3}-\mathrm{N}$ in fresh slurry. Ammonia concentration was higher in samples harvested in season I, when the average outside temperatures were higher (Table 5); the relationship between temperature and ammonia evaporation will be discussed later.

In stored manure, average $\mathrm{N}$ concentration $(\mathrm{g} / \mathrm{kg}$ of FM) in the pool-stored manure or in the compost bedded pack (3.9 and 11.7, respectively) were within the range proposed by Velthof et al. (2015) for pool-stored slurry $(4.0 \pm 0.7 \mathrm{~g} / \mathrm{kg}$ of FM) and compost-bedded packs $(7.7 \pm 5.7 \mathrm{~g} / \mathrm{kg}$ of FM).

Dry matter concentration in compost beds was within the range reported by other authors (Atzori et al., 2009; Bjerg and Klaas, 2014). Daily treatment (including mechanical labor and cow interactions) of compost beds favored water evaporation, and thus DM concentration increased. This increase in DM content was more pronounced during season II, when temperatures were decreasing. However, no effect from season was significant in pool-stored manure.

Compost-bedded pack management enhanced $\mathrm{N}$ volatilization, resulting in a reduction of absolute values for both $\mathrm{NH}_{3}-\mathrm{N}$ and total $\mathrm{N}$ concentration. However, differences in $\mathrm{N}$ concentration between fresh and aged manure were influenced by DM concentration in the bedded pack manure. Both $\mathrm{P}$ and $\mathrm{K}$ are elements shown to be more stable in manure (Atzori et al., 2009), and their ratios with other compounds may provide a reliable index of absolute values of $\mathrm{N}$ losses when the $\mathrm{N}: \mathrm{P}$ ratios of fresh and aged materials are compared (Todd et al., 2005; Moreira and Satter, 2006). Nitrogen losses based on the model proposed by Moreira and Satter (2006) $\left[\mathrm{N}\right.$ losses $=\left[1-\left(\mathrm{N}: \mathrm{P}_{\text {stored excreta }} / \mathrm{N}: \mathrm{P}_{\text {fresh excreta }}\right)\right]$ $\times 100]$ were $7.1 \%( \pm 2.61)$ in CUB, whereas those recorded in CB were $32.7 \%( \pm 4.54)$; effectively, N:P ratio provided evidence of increasing $\mathrm{N}$ losses by volatilization in the composting bed system. However, it is important to note that $\mathrm{N}: \mathrm{P}$ ratio-derived estimations should be treated with caution. Phosphorus is mostly excreted through feces in insoluble form, whereas $\mathrm{N}$ is excreted mostly through urine under urea-soluble form; therefore, any bias in the distribution between urine and feces (i.e., excreta distribution between alleys and bed packs) or loss through runoff during the sampling of fresh slurry may cause a bias in the ratio N:P. 
Potassium may constitute an alternative internal fecal standard because, like $\mathrm{N}$, it is found in both feces and urine (Gustafson and Olsson, 2004); however, its excretion in urine only occurs when intake exceeds the K requirements (Underwood and Suttle, 2001). Thus, $\mathrm{P}$ uncertainties are not fully compensated for when using $\mathrm{K}$ as the internal marker. Hristov et al. (2009) reported reasonable results when comparing $\mathrm{N}$ mass balance against both $\mathrm{N}: \mathrm{P}$ and $\mathrm{N}: \mathrm{K}$ ratios, but in our case, $\mathrm{K}$ concentrations in fresh and aged samples were less consistent than $\mathrm{P}$ concentration; consequently, only the latter was used as an internal fecal standard.

\section{Nitrogen Balance at the Herd Level}

In the present study, herd mass balance of $\mathrm{N}$ was calculated as the difference between $\mathrm{N}$ input and output; therefore, several assumptions were needed to apply the previous equations. For instance, changes in the animals' body proteins should be minimal because protein mobilization in cows after parturition or early lactation (Komaragiri et al., 1998) can be compensated for by accretion of those animals placed during mid to late lactation (Andrew et al., 1995). In fact, any variation in animal distribution could lead to an alteration in the $\mathrm{N}$ balance and increase the experimental error. To avoid any imbalance in the animal distribution, the experimental program was initially discussed with the farmers, although sporadic changes in herd size were unpredictable. Dermal and scurf $\mathrm{N}$ losses recovered in manure may have also altered the $\mathrm{N}$ mass balance, but this source of error should have minor relevance (Agricultural and Food Research Council, 1993).

Nitrogen balance presented in our study fit well within the intervals proposed in the meta-analysis (European data sets; $\mathrm{n}=998$ ) published by Huhtanen and Hristov (2009), in which $\mathrm{N}$ intake varied between 480 and $624 \mathrm{~g} / \mathrm{d}$, milk $\mathrm{N}$ excretion between 24.7 and $27.7 \%$ of $\mathrm{N}$ intake, and $\mathrm{N}$ losses between 430 and $470 \mathrm{~g} / \mathrm{d}$, respectively. However, variability of aspects affecting irreversible $\mathrm{N}$ losses is extremely challenging (Hristov et al., 2011). Analyzed data on $\mathrm{NH}_{3}$ emissions from conventional dairy facilities (CUB barns) revealed that $\mathrm{N}$ losses (defined as $\mathrm{NH}_{3}$ emission) averaged $59 \mathrm{~g}$ of $\mathrm{N} /$ cow per day, which was lower than values obtained in the present approach $(73.6 \pm 12.31 \mathrm{~g}$ of $\mathrm{N} /$ cow per day). The authors recognize that the reported values should be treated with caution due to the wide range determined, between 0.82 to $250 \mathrm{~g}$ of $\mathrm{N} /$ cow per day.

When only data obtained from the mass $\mathrm{N}$ balance in conventional solid floor cubicle (CUB) system are considered (building facilities plus manure storage pools), irreversible $\mathrm{N}$ losses varied from 72 to $129 \mathrm{~g}$ of $\mathrm{N} / \mathrm{cow}$ per day, which agrees with previous authors (Moreira and Satter, 2006; Cole and Todd, 2009; Aguerre et al., 2010; Hristov et al., 2011).

Using compost-bedded pack as a housing system has become popular for reducing the volume and weight of livestock manure (Inbar et al., 1993). Mechanical disruption of the bedded pack in CB (including farming plus animal interactions, such as stepping, walking, and lying) alters the chemical composition of composting manure. In this sense, Eghball et al. (1997) showed that by composting the manure in this way, between 19 and $45 \%$ of initial $\mathrm{N}$ is lost. In our case, $\mathrm{N}$ losses (related to $\mathrm{N}$ intake) derived from bedded pack management reached values of $42 \%$ and were much higher than those values $(11 \%)$ recorded in conventional solid floor $\mathrm{cu}^{-}$ bicles (CUB; Table 6). Estimations of $\mathrm{N}$ losses from CB were higher using mass $\mathrm{N}$ balance estimates (42.3\%) than using N:P ratio (32.7\%), although as discussed above, the instability in the N:P ratio may have led to some bias in these latter estimations.

Data related to irreversible $\mathrm{N}$ losses coming from composting bed systems are scarce. Our values fit reasonably well into the range proposed by Rotz (2004), from 25 to $40 \%$ ( $\mathrm{N}$ losses/N excretion), with an average value of $35 \%$. These values were confirmed by Atzori et al. (2009), who found a mean annual $\mathrm{N}$ volatilization percentage ( $\mathrm{N}$ lost/excreted) of $38.8 \%$ measured in the area covered with bedded pack; however, in the feeding and walking areas, $\mathrm{N}$ volatilization reached $42.5 \%$ of total $\mathrm{N}$ excreted.

Ammonia accounts for the primary source of $\mathrm{N}$ volatilization (de Vries et al., 2003; Seradj et al., 2018); $\mathrm{NH}_{3}-\mathrm{N}$ emissions are mostly generated in the upper layer where urinary urea is rapidly hydrolyzed to $\mathrm{NH}_{3}$ by oxygen-dependent ureases (James et al., 1999), which diffuses at the manure air-water interface and is partially emitted to the atmosphere. In this scenario, both ammonium $\left(\mathrm{NH}_{4}^{+}\right)$and $\mathrm{NH}_{3}-\mathrm{N}$ coexist in an equilibrium determined by both $\mathrm{pH}$ and temperature (Ndegwa et al., 2008).

By increasing the $\mathrm{pH}$, balance is shifted toward $\mathrm{NH}_{3}-$ $\mathrm{N}$, and then $\mathrm{N}$ volatilization increases exponentially. The $\mathrm{pH}$ level at the manure surface (where most $\mathrm{NH}_{3}$ volatilizes) determines $\mathrm{NH}_{3}$ emission rate. When manure is exposed to air, dissolved $\mathrm{CO}_{2}$ is released faster than $\mathrm{NH}_{3}$ due to its lower solubility. Therefore, rapid $\mathrm{CO}_{2}$ evaporation increases surface $\mathrm{pH}$, whereas $\mathrm{pH}$ in the bulks remains relatively constant (Sommer et al., 2006). Montes et al. (2009) demonstrated that by continuous manure mixing, $\mathrm{pH}$ at the surface may increase by 1 unit with respect to bulk manure $\mathrm{pH}$. Mechanical aeration, constant animal movement, and mixing of feces and urine as occur into the compost bedded pack system (Todd et al., 2006) could explain the increase in irreversible $\mathrm{N}$ losses compared with conventional CUB 
systems, in which manure remains stored in a more stable condition.

Degradation of fecal protein may also constitute an additional source of $\mathrm{NH}_{3}$ in the upper layer, but in a minor proportion (Maier et al., 2009). Lower bed layers also contribute to gas emissions, mostly as $\mathrm{CH}_{4}$, but also as $\mathrm{NH}_{3}$, which moves upward (Goyal et al., 2005), although this fraction would likely be less affected by bedded pack farming.

Increasing temperature enhances urease activity (Powell et al., 2008b), the dissociation of $\mathrm{NH}_{4}-\mathrm{N}$ to $\mathrm{NH}_{3} \mathrm{~N}$ (Srinath and Loehr, 1974), and hence, $\mathrm{NH}_{3}$ volatilization. In relation to the former, urease activity is temperature-dependent, being relatively low below $10^{\circ} \mathrm{C}$ but increasing rapidly after that point (Braam et al., 1997); thus, over that threshold, a positive correlation between temperature and $\mathrm{NH}_{3}$ volatilization has been described by several authors. Smits et al. (1995) described an increase of $3.8 \%$ in $\mathrm{NH}_{3}$ volatilization per temperature degree increase. This finding was similar to the increase $(2.9 \%)$ proposed by Kroodsma et al. (1993), although other authors (Powell et al., 2008a) could not confirm any relationship between $\mathrm{N}$ losses and temperature. In our case, irreversible $\mathrm{N}$ losses were measured during 2 seasons, when temperature was either increasing or decreasing (Figure 1). However, in the present study, differences between average temperatures (16.5 vs. $12.3^{\circ} \mathrm{C}$ for seasons I and II, respectively) were probably too low to discriminate potential changes in $\mathrm{N}$ losses from the experimental error $(\mathrm{CV}=9.21 \%)$. It is also true that during manure storage, both bacteria and fungi liberate energy from $\mathrm{OM}$ decomposition, and endogenous heat generation can bias a direct effect between outside temperature and $\mathrm{N}$ evaporation.

Figure 1 shows the wind profile throughout the experimental period. On average, wind speed of 1.38 $\mathrm{m} / \mathrm{s}$ (0.060 SEM) fell within the range proposed by the available literature $[0.5-7 \mathrm{~m} / \mathrm{s}$, averaging $3.1 \mathrm{~m} / \mathrm{s}$ (1.5 SEM), $\mathrm{n}=35$; Bjorneberg et al., 2009; Ngwabie et al., 2009; Leytem et al., 2011, 2013]. In our study, wind speed was not constant and the winter-spring season was windier and showed a high variance, as a measure of change in wind speed or direction, although it did not affect $\mathrm{N}$ losses between seasons (Table 6). Ammonia volatilization depends on the mass transfer coefficient, so it could be affected by wind speed at manure level (Snoek et al., 2014). Nevertheless, our data were not taken at the manure level and it is known that air speed may be highly variable within an individual barn. In any case, the difficulty in discriminating the effect of wind from other climatological features (e.g., temperature) has been suggested previously (Leytem et al., 2011), and a limited relationship between wind speed and $\mathrm{NH}_{3}$ emission was demonstrated by metaanalysis (Sanchis et al., 2019).

\section{CONCLUSIONS}

Application of herd-level $\mathrm{N}$ mass balance studies is a valuable tool by which to study changes in irreversible $\mathrm{N}$ losses in response to different housing systems and seasonal conditions reflecting commercial farmlike conditions in the semi-arid part of northeastern Spain. This study demonstrated that housing system alters the balance between the fraction of $\mathrm{N}$ recovered into slurry and the fraction lost by volatilization, with compost bedded systems showing a higher loss rate. Although the work was carried out in 2 seasons, the differences in average temperature were not sufficient to demonstrate a temperature effect on $\mathrm{NH}_{3}-\mathrm{N}$ emissions during manure storage. Our results clearly illustrated the potential effect of manure management systems on real values in terms of $\mathrm{N}$ balance, and emissions.

\section{ACKNOWLEDGMENTS}

The authors thank the staff and employees of the commercial farms (Ramaderia Gonzàlez, La Saireta, Cal Serre, Ramaderia Fontanals, Cal Perches, and Cal Padrí) for their collaboration in the project. We also thank to Carlos Cantero (University of Lleida, Lleida, Spain) for his help during sample collections. This study was funded by Generalitat de Catalunya, Department of Agriculture, Livestock, Fisheries, and Food (Barcelona, Spain; S-18017). The authors have not stated any conflicts of interest.

\section{REFERENCES}

Agricultural and Food Research Council. 1993. Energy and protein requirements of ruminants CAB International, Wallingford, UK.

Aguerre, M. J., M. A. Wattiaux, T. Hunt, and B. R. Larget. 2010. Effect of dietary crude protein on ammonia-N emission measured by herd nitrogen mass balance in a freestall dairy barn managed under farm-like conditions. Animal 4:1390-1400. https://doi.org/ 10.1017/S1751731110000248.

Andrew, S. M., R. A. Erdman, and D. R. Waldo. 1995. Prediction of body composition of dairy cows at three physiological stages from deuterium oxide and urea dilution. J. Dairy Sci. 78:1083-1095. https://doi.org/10.3168/jds.S0022-0302(95)76725-X.

AOAC International. 2010. Official Methods of Analysis. in 18th ed. AOAC International, Arlington, VA.

Atzori, A. S., R. Boe, P. Carta, A. Fenu, G. Spanu, A. H. Dias Francesconi, and A. Cannas. 2009. Estimation of nitrogen volatilisation in the bedded-pack of dairy cow barns. Ital. J. Anim. Sci. 8(Suppl. 2):253-255. https://doi.org/10.4081/ijas.2009.s2.253.

Barberg, A. E., M. I. Endres, J. A. Salfer, and J. K. Reneau. 2007. Performance and welfare of dairy cows in an alternative housing system in Minnesota. J. Dairy Sci. 90:1575-1583. https://doi.org/ 10.3168/jds.S0022-0302(07)71643-0. 
Bjerg, B., and I. Klaas. 2014. Water and ammonia evaporation in a compost bedded pack dairy barn with under floor aeration. Proc. 2014 ASABE and CSBE/SCGAB Annual International Meeting, Montreal, QC, Canada. American Society of Agricultural and Biological Engineers, St. Joseph, MI. https://doi.org/10.13031/ aim.20141899106.

Bjorneberg, D. L., A. B. Leytem, D. T. Westermann, P. R. Griffiths, L. Shao, and M. J. Pollard. 2009. Measurement of atmospheric ammonia, methane, and nitrous oxide at a concentrated dairy production facility in southern Idaho using open-path FTIR spectrometry. Trans. ASABE 52:1749-1756. https://doi.org/10.13031/ 2013.29137.

Braam, C. R., J. J. M. H. Ketelaars, and M. C. J. Smits. 1997. Effects of floor design and floor cleaning on ammonia emission from cubicle houses for dairy cows. Neth. J. Agric. Sci. 45:49-64.

Bristow, A. W., D. C. Whitehead, and J. E. Cockburn. 1992. Nitrogenous constituents in the urine of cattle, sheep and goats. J. Sci. Food Agric. 59:387-394. https://doi.org/10.1002/jsfa.2740590316.

Cole, N. A., and R. W. Todd. 2009. Nitrogen and phosphorus balance of beef cattle feedyards. Pages 17-24 in Proc. Texas Animal Manure Management Issues Conf., Round Rock, TX.

de Vries, S., R. A. Verheij, P. P. Groenewegen, and P. Spreeuwenberg. 2003. Natural environments - Healthy environments? An exploratory analysis of the relationship between greenspace and health. Environ. Plan. A. Economy Space 35:1717-1731. https://doi.org/ 10.1068/a35111

Eghball, B., J. F. Power, J. E. Gilley, and J. W. Doran. 1997. Nutrient, carbon, and mass loss during composting of beef cattle feedlot manure. J. Environ. Qual. 26:189-193. https://doi.org/10.2134/ jeq1997.00472425002600010027x.

FEFRIC. 2018. Federación Frisona de Catalunya. http://www.fefric .com/documents/controllleter/78_resum_anual_2015.pdf.

Galama, P. J. 2011. Prospects for bedded pack barns for dairy cattle. Wageningen UR Livestock Research, Lelystad, the Netherlands.

de Catalunya, G. 2009. DECRET 136/2009, d'1 de setembre, d'aprovació del programa d'actuació aplicable a les zones vulnerables en relació amb la contaminació de nitrats que procedeixen de fonts agràries i de gestió de les dejeccions ramaderes. DOGC, Barcelona, Spain.

Goyal, S., S. K. Dhull, and K. K. Kapoor. 2005. Chemical and biological changes during composting of different organic wastes and assessment of compost maturity. Bioresour. Technol. 96:1584-1591. https://doi.org/10.1016/j.biortech.2004.12.012.

Gustafson, G. M., and I. Olsson. 2004. Partitioning of nutrient and trace elements in feed between body retention, faeces and urine by growing dairy-breed steers. Acta Agric. Scand. A Anim. Sci. 54:10-19. https://doi.org/10.1080/09064700410024346.

Harper, L. A. 2005. Ammonia: Measurement issues. Pages 345-379 in Micrometeorological Measurements in Agricultural Systems. J. L. Hatfield, and J. M. Baker, ed. ASA-CSSA-SSSA Annual Meetings. Madison, WI. https://doi.org/10.2134/agronmonogr47.c15.

Hristov, A. N., M. Hanigan, A. Cole, R. Todd, T. A. McAllister, P. M. Ndegwa, and A. Rotz. 2011. Review: Ammonia emissions from dairy farms and beef feedlots. Can. J. Anim. Sci. 91:1-35. https:/ /doi.org/10.4141/CJAS10034.

Hristov, A. N., S. Zaman, M. Vander Pol, P. Ndegwa, L. Campbell, and S. Silva. 2009. Nitrogen losses from dairy manure estimated through nitrogen mass balance and chemical markers. J. Environ. Qual. 38:2438-2448. https://doi.org/10.2134/jeq2009.0057.

Huhtanen, P., and A. N. Hristov. 2009. A meta-analysis of the effects of dietary protein concentration and degradability on milk protein yield and milk N efficiency in dairy cows. J. Dairy Sci. 92:32223232. https://doi.org/10.3168/jds.2008-1352.

Inbar, Y., Y. Hadar, and Y. Chen. 1993. Recycling of cattle manure: The composting process and characterization of maturity. J. Environ. Qual. 22:857-863. https://doi.org/10.2134/jeq1993 $.00472425002200040032 \mathrm{x}$.

James, T., D. Meyer, E. Esparza, E. J. Depeters, and H. Perez-Monti. 1999. Effects of dietary nitrogen manipulation on ammonia volatilization from manure from Holstein heifers. J. Dairy Sci. 82:24302439. https://doi.org/10.3168/jds.S0022-0302(99)75494-9.
Janni, K. A., M. I. Endres, J. K. Reneau, and W. W. Schoper. 2007. Compost dairy barn layout and management recommendations. Appl. Eng. Agric. 23:97-102. https://doi.org/10.13031/2013 .22333 .

Klaas, I. C., B. Bjerg, S. Friedmann, and D. Bar. 2010. Cultivated barns for dairy cows - An option to promote cattle welfare and environmental protection in Denmark? Dansk Vettidsskr. 93:20-29.

Komaragiri, M. V. S., D. P. Casper, and R. A. Erdman. 1998. Factors affecting body tissue mobilization in early lactation dairy cows. 2. Effect of dietary fat on mobilization of body fat and protein. J. Dairy Sci. 81:169-175. https://doi.org/10.3168/jds.S0022 -0302(98)75564-X.

Kroodsma, W., J. W. H. Huis in 't Veld, and R. Scholtens. 1993 Ammonia emission and its reduction from cubicle houses by flushing. Livest. Prod. Sci. 35:293-302. https://doi.org/10.1016/0301 -6226(93)90099-4.

Leytem, A. B., R. S. Dungan, D. L. Bjorneberg, and A. C. Koehn. 2011. Emissions of ammonia, methane, carbon dioxide, and nitrous oxide from dairy cattle housing and manure management systems. J. Environ. Qual. 40:1383-1394. https://doi.org/10.2134/jeq2009 .0515 .

Leytem, A. B., R. S. Dungan, D. L. Bjorneberg, and A. C. Koehn. 2013. Greenhouse gas and ammonia emissions from an openfreestall dairy in southern Idaho. J. Environ. Qual. 42:10-20. https://doi.org/10.2134/jeq2012.0106.

Lobeck, K. M., M. I. Endres, E. M. Shane, S. M. Godden, and J. Fetrow. 2011. Animal welfare in cross-ventilated, compost-bedded pack, and naturally ventilated dairy barns in the upper Midwest. J. Dairy Sci. 94:5469-5479. https://doi.org/10.3168/jds.2011-4363.

Maier, R., I. Pepper, and C. Gerba. 2009. Environmental Microbiology. 2nd ed. Academic Press, San Diego, CA.

Monteny, G. J., D. D. Schulte, A. Elzing, and E. J. J. Lamaker. 1998. A conceptual mechanistic model for the ammonia emissions from free stall cubicle dairy cow houses. Trans. ASAE 41:193-201. https://doi.org/10.13031/2013.17151.

Montes, F., C. A. Rotz, and H. Chaoui. 2009. Process modeling of ammonia volatilization from ammonium solution and manure surfaces: A review with recommended models. Trans. ASABE 52. https://doi.org/10.13031/2013.29133.

Moreira, V. R., and L. D. Satter. 2006. Effect of scraping frequency in a freestall barn on volatile nitrogen loss from dairy manure. J. Dairy Sci. 89:2579-2587. https://doi.org/10.3168/jds.S0022 $-0302(06) 72334-7$.

MWPS. 2001. Manure Storages. Manure Management System Series MWPS-18, Section 2. MidWest Plan Service, Iowa State University, Ames.

Ndegwa, P. M., A. N. Hristov, J. Arogo, and R. E. Sheffield. 2008. A review of ammonia emission mitigation techniques for concentrated animal feeding operations. Biosyst. Eng. 100:453-469. https:// doi.org/10.1016/j.biosystemseng.2008.05.010.

Ngwabie, N. M., K. H. Jeppsson, S. Nimmermark, C. Swensson, and G. Gustafsson. 2009. Multi-location measurements of greenhouse gases and emission rates of methane and ammonia from a naturally-ventilated barn for dairy cows. Biosyst. Eng. 103:68-77. https:/ /doi.org/10.1016/j.biosystemseng.2009.02.004.

Observatory of Milk and Beef Production. 2018. Temporary data of dairy cattle production in Catalonia. Observatori de la llet. Gabinet tècnic. Departament d'agricultura i Acció Rural. Generalitat de Catalunya, Spain.

Porta, J., M. López-Acevedo, and R. Rodríguez. 1982. Técnicas y experimentos en edafología. Ed. Universitat de Lleida, Lleida, Spain.

Powell, J. M., G. A. Broderick, and T. H. Misselbrook. 2008a. Seasonal diet affects ammonia emissions from tie-stall dairy barns. J. Dairy Sci. 91:857-869. https://doi.org/10.3168/jds.2007-0588.

Powell, J. M., D. B. Jackson-Smith, D. F. McCrory, H. Saam, and M. Mariola. 2006. Validation of feed and manure data collected on Wisconsin dairy farms. J. Dairy Sci. 89:2268-2278. https://doi .org/10.3168/jds.S0022-0302(06)72298-6.

Powell, J. M., T. H. Misselbrook, and M. D. Casler. 2008b. Season and bedding impacts on ammonia emissions from tie-stall dairy barns. J. Environ. Qual. 37:7-15. https://doi.org/10.2134/jeq2007.0282. 
Reneau, J. K., A. J. Seykora, B. J. Heins, M. I. Endres, R. J. Farnsworth, and R. F. Bey. 2005. Association between hygiene scores and somatic cell scores in dairy cattle. J. Am. Vet. Med. Assoc. 227:1297-1301. https://doi.org/10.2460/javma.2005.227.1297.

Rotz, C. A. 2004. Management to reduce nitrogen losses in animal production. J. Anim. Sci. 82(Suppl_13):E119-E137. https://doi .org/10.2527/2004.8213_supplE119x.

Sanchis, E., S. Calvet, A. Prado, and F. Estellés. 2019. A meta-analysis of environmental factor effects on ammonia emissions from dairy cattle houses. Biosyst. Eng. 178:176-183. https://doi.org/10 .1016/j.biosystemseng.2018.11.017.

Seradj, A. R., J. Balcells, H. Morazan, J. Alvarez-Rodriguez, D. Babot, and G. De la Fuente. 2018. The impact of reducing dietary crude protein and increasing total dietary fiber on hindgut fermentation, the methanogen community and gas emission in growing pigs. Anim. Feed Sci. Technol. 245:54-66. https://doi.org/10 .1016/j.anifeedsci.2018.09.005.

Shane, E. M., M. I. Endres, and K. A. Janni. 2010. Alternative bedding materials for compost bedded pack barns in Minnesota: A descriptive study. Appl. Eng. Agric. 26:465-473. https://doi.org/ $10.13031 / 2013.29952$.

Smits, M. C. J., H. Valk, A. Elzing, and A. Keen. 1995. Effect of protein nutrition on ammonia emission from a cubicle house for dairy cattle. Livest. Prod. Sci. 44:147-156. https://doi.org/10.1016/0301 -6226(95)00068-6.

Snoek, D. J. W., J. D. Stigter, S. K. Blaauw, P. W. G. Groot Koerkamp, and N. W. M. Ogink. 2017. Assessing fresh urine puddle physics in commercial dairy cow houses. Biosyst. Eng. 159:133-142. https:// doi.org/10.1016/j.biosystemseng.2017.04.003.

Snoek, D. J. W., J. D. Stigter, N. W. M. Ogink, and P. W. G. Groot Koerkamp. 2014. Sensitivity analysis of mechanistic models for estimating ammonia emission from dairy cow urine puddles. Biosyst.
Eng. 121:12-24. https://doi.org/10.1016/j.biosystemseng.2014.02 .003 .

Sommer, S. G., L. S. Jensen, S. B. Clausen, and H. T. Søgaard. 2006. Ammonia volatilization from surface-applied livestock slurry as affected by slurry composition and slurry infiltration depth. J. Agric. Sci. 144:229-235. https://doi.org/10.1017/S0021859606006022.

Srinath, E. G., and R. C. Loehr. 1974. Ammonia desorption by diffused aeration. J. Water Pollut. Control Fed. 46:1939-1957.

Todd, R. W., N. A. Cole, and R. N. Clark. 2006. Reducing crude protein in beef cattle diet reduces ammonia emissions from artificial feedyard surfaces. J. Environ. Qual. 35:404-411. https://doi.org/ 10.2134/jeq2005.0045.

Todd, R. W., N. A. Cole, L. A. Harper, T. K. Flesch, and B. H. Baek. 2005. Ammonia and gaseous nitrogen emissions from a commercial beef cattle feedyard estimated using the flux-gradient method and N:P ratio analysis. Pages 1-8 in Proc. State Sci.: Animal Manure and Waste Management. San Antonio, TX

Underwood, E. J., and N. F. Suttle. 2001. The Mineral Nutrition of Livestock. 3rd ed. Commonwealth Agricultural Bureaux, Wallingford, UK.

Van Soest, P. J., J. B. Robertson, and B. A. Lewis. 1991. Methods for dietary fiber, neutral detergent fiber, and nonstarch polysaccharides in relation to animal nutrition. J. Dairy Sci. 74:3583-3597. https://doi.org/10.3168/jds.S0022-0302(91)78551-2.

Velthof, G. L., Y. Hou, and O. Oenema. 2015. Nitrogen excretion factors of livestock in the European Union: A review. J. Sci. Food Agric. 95:3004-3014. https://doi.org/10.1002/jsfa.7248.

White, S. L., J. A. Bertrand, M. R. Wade, S. P. Washburn, J. T. Green Jr., and T. C. Jenkins. 2001. Comparison of fatty acid content of milk from Jersey and Holstein cows consuming pasture or a total mixed ration. J. Dairy Sci. 84:2295-2301. https://doi.org/10.3168/ jds.S0022-0302(01)74676-0. 